\title{
MANCHESTER
}

1824

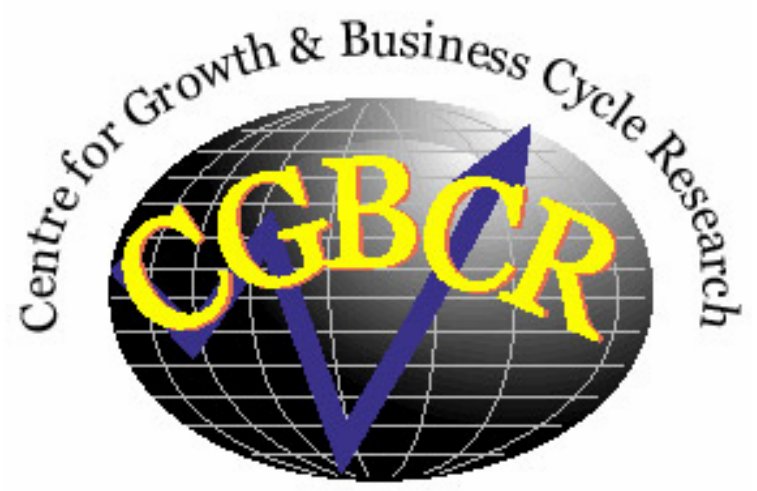

Discussion Paper Series

\section{Income Inequality and Colonialism}

By

\section{Luis Angeles}

Centre for Growth and Business Cycle Research, Economic Studies, University of Manchester, Manchester, M13 9PL, UK

November 2005

Number 066

Download paper from:

http://www.ses.man.ac.uk/cgbcr/discussi.htm 


\title{
Income Inequality and Colonialism
}

\author{
Luis Angeles* \\ June 2005
}

\begin{abstract}
This paper proposes that Colonialism is a major explanation behind today's differences in Income Inequality among countries. We argue that colonies that received an important number of European settlers were characterized by a concentration of economic and political power in the hands of these last ones. Moreover, European settlers later achieved independence from the metropolis and were able to prolong the status quo. Colonies where Europeans were much less present did not develop such strong inequality. The empirical evidence we provide strongly supports our thesis.
\end{abstract}

JEL classification: O15; O13; N90

Keywords: Colonialism, Inequality, Income distribution.

\section{Introduction}

In the last few years a considerable number of papers have increased our understanding of the way the colonial experience of today's developing countries has influenced their future economic evolution. While the analysis of many short term issues might be safely done without considering the historical context of each country, such an approach would be highly dubious for long term problems like differences in income levels between rich and poor nations.

It is precisely their careful consideration of History in general, and of Colonial History in particular, what sets papers like Acemoglu et al. (2001 and

*Department of Economics, School of Social Sciences, The University of Manchester. e-mail: Luis.Angeles@manchester.ac.uk. Tel: +44 161275 4855. I thank two anonimous referees and participants at the LACEA meeting 2003 for their very helpful comments. 
2002) or Engerman and Sokoloff (2002) aside among those addressing the question of why southern countries have not attained the economic well-being of the world's industrial countries. Acemoglu et al. (2001) argue that the pattern of European settlement in the colonies determined the type of institutions that these countries developed and that these institutions are a major factor behind their economic backwardness. In those regions where few Europeans settled, Europeans created "extractive states" and the resulting institutions "...did not introduce much protection for private property, nor did they provide checks and balances against government expropriation." On the other hand, the authors also propose that the countries that received a large number of settlers "tried to replicate European institutions" and therefore created the right set of rules encouraging future economic growth. European migration to a given region was largely determined by the mortality rates that future settlers would face. This provided the authors with an instrument to test the effect of institutions on the level of GDP per capita, namely the mortality rates of European settlers in colonial times.

Engerman and Sokoloff (2002) provide us with a convincing account of how many of the differences in economic outcomes between the northern and the southern part of the American Continent are rooted in colonial times. The authors identify as the initial cause of this divergence the differences in factor endowments that Europeans found in the New World. The southern part of the continent, with its aptitude for sugar production and mining, started with a much more pyramidal society than the northern one, with its family-size agricultural units. Engerman and Sokoloff "document - through comparative studies of suffrage, public land and schooling policies - systematic patterns by which societies in the Americas that began with more extreme inequality or heterogeneity in the population were more likely to develop institutional structures that greatly advantaged members of the elite classes (...) by providing them with more political influence and access to economic opportunities."

The present paper places itself in the same line as the two aforementioned ones. Like them, it studies a long run distinction between developed and developing countries in the light of the Colonial past of the later. The object of our study is the large differences in income inequality that exist among countries of the world. Using the most popular measure of inequality, namely the Gini coefficient, we can observe that the countries of Latin America and sub-Saharan Africa have much higher levels of inequality than those prevailing in Europe or Asia. The average value of the Gini coefficient is 51.80 for Latin America and 46.85 for sub-Saharan Africa while for Western Europe and South 
and East Asia the values are 31.83 and 37.71 respectively ${ }^{1}$.

The only explanation for these important differences that has ever gained wide approval among the economics profession is the "Kuznets' hypothesis". Proposed by Kuznets (1955), it asserts that inequality should evolve following an "inverted U" pattern as countries develop. Although initial tests of Kuznets' hypothesis gave contrasting results ${ }^{2}$, the issue could finally be settled once comprehensive time series data on inequality became available for a large number of countries. This happened in the mid nineties thanks to the work of Deininger and Squire (1996). Tests using this data set showed Kuznets' hypothesis to be wrong ${ }^{3}$.

The main proposition of this paper is that different experiences during the Colonial Period are a major explanation behind today's differences in inequality among countries. In an econometric analysis we show the effect to be quantitatively large and robust to the inclusion of a series of controls. We use an objective measure in order to differentiate the diverse colonial experiences the World has known in the last five centuries. This measure is the percentage of European settlers living in the colony at its apogee. We hypothesize that the higher this percentage the greater the inequality in the country, as long as Europeans stayed a minority.

There are only four cases where the European immigrants became the majority of the population: Australia, Canada, New Zealand and the United States. We will refer to these countries as the "New Europes", an appropriate label since together with the people came much of the institutional framework of Western Europe (these were all British colonies). These colonies were different from the rest of the colonial world in most aspects, one of them was their relatively even distribution of national income.

For the rest of the World a positive relationship between European settlement and inequality does exist. Basically, there were two types of strategies adopted by the colonial powers in today's developing countries ${ }^{4}$. The first one,

\footnotetext{
${ }^{1}$ Calculated using the latest available data for each country. Note that these numbers are given for illustrative purpose only since we have not taken into account differences in income and income recipient definitions (see below).

${ }^{2}$ For instance, Ahluwalia (1976) found support for the inverted U hypothesis but this was proved not to be robust by Anand and Kanbur (1993b).

${ }^{3}$ Deininger and Squire (1998) find in a panel data regression with 49 countries that for 40 among them there is no statistically significant association between income per capita and inequality; for 5 countries there is an "inverted U" relationship and for 4 countries there is a "U shaped" relationship.

${ }^{4} \mathrm{~A}$ similar clasification can be found in the works of historians of colonialism. See for instance Waites (1999).
} 
which lead to the creation of what we will call "Settler Colonies", allowed a large number of Europeans to establish themselves overseas. The ratio of European to total population in these colonies was in the range of 0.10 to 0.30 . Such an important number of newcomers was able to appropriate most of the country's productive resources for themselves. This was especially true for the arable land and the mining resources. The indigenous people, together with the imported slaves which characterized many of these colonies, had much more restricted access to land and were often left with working in the European's mines or plantations as their only alternative. Accordingly, their living standards were far below those of the European minority. These colonies were thus characterized by very high inequality levels.

The second type of colonies received a much more reduced number of Europeans, mainly for the purposes of administration and tax collection but nor for running agricultural exploitations themselves. We will refer to these cases as "Peasant Colonies" since the agricultural production stayed in the hands of local peasants. The percentage of Europeans in these colonies was typically well below $1 \%$. Although there is considerable heterogeneity in this group of colonies we can say that as a rule inequality was not severely increased with respect to pre colonial times. Europeans usually left the ownership of the land to the indigenous people and contented themselves with taxing their production and inducing them to shift their traditional products for more commercial ones like tea, coffee or cacao. The strain put on local populations by the colonizers was thus comparable to the one a local prince would have induced anyway ${ }^{5}$. We hypothesize that inequality in these countries was not necessarily higher than in non colonized ones.

We analyze empirically the effect of colonialism on inequality by including as an explanatory variable of inequality either the ratio of European settlers to total population or dummies for each type of Colony. Both approaches give a similar result: the effect of these variables is not only statistically significant but also larger than that of any other variable.

Our paper distinguish itself from the ones mentioned before in important ways. Acemoglu et al. (2001) is concerned mainly with institutions and growth, inequality is not really analyzed. Engerman and Sokoloff (2002) do discuss the issue of inequality but they limit themselves to the American Continent and do not offer a quantitative analysis like we do. We can also mention the empirical works of Bertocchi and Canova (2002) and Grier (1999), who are concerned with the effect of colonialism on economic growth.

\footnotetext{
${ }^{5}$ There are, of course, some exceptions like the Belgian Congo where European activity was particularly devastating.
} 
One aspect that the present paper does have in common with the ones by Acemoglu et al. (2001) or Engerman and Sokoloff (2002) is that it stresses the continuity of the colonial order after colonization was over, at least in some places. This is at the center of the thesis of Acemoglu et al. (2001), where one of the three premises their whole paper is based on is "The colonial state and institutions persisted even after independence." They are not alone in holding this view, since many historians would agree with them. First among them Engerman and Sokoloff (2002), who referring to the case of Mexico say: "The evidence obviously conforms well with the idea that in societies that began with extreme inequality, such as Mexico, institutions evolved so as to greatly advantage the elite in access to economic opportunities, and they thus contributed to the persistence of that extreme inequality."

The hypothesis that we will make is less demanding than that of Acemoglu et al. (2001) since we will propose that the main characteristics of the colonial period persisted after independence in the countries of important European settlement. We do not require this for the countries where European settlement was very low or for the "New Europes". We will defend this and other views we have on colonization in the following section.

Another strain of the literature that can be related to our paper treats inequality as an endogenous outcome that depends on initial conditions and some market imperfections. We are referring mainly to the theoretical literature on inequality and growth that developed in the nineties (and that was accompanied by a large empirical literature). Several papers in this literature suggest that under some conditions an economy can have multiple equilibria that greatly differ in terms of both inequality and growth. Thus, the initial conditions of the economy, for instance the initial distribution of wealth, might lead the country into an undesirable equilibria of low growth and high inequality. The models of Banerjee and Newman (1993), Galor and Zeira (1993), Aghion and Bolton (1997) and Bénabou (1996) are good examples of this literature. These models use an imperfect credit market as the source of their results. In Banerjee and Newman (1993), an economy with an initial distribution of income that is strongly unequal will see a large part of its population excluded from the credit market. This exclusion will not allow poorer people to invest in physical and human capital, reducing the growth rate of the economy and perpetuating the high inequality situation. Bénabou (1996) also sees inequality as potentially self-reinforcing, but he stresses other channels. He argues that in high inequality countries policies of redistribution would not find enough support from rich indivuduals since the transfers they would be required to make would be too large with respect to the potential 
gains that stem from a faster growing economy. Other authors who have also studied the political dimension of the problem are Alesina and Rodrik (1994) and Persson and Tabellini (1994). Their view is somewhat opposed to that of Bénabou (1996) in the sense that they see redistribution as a nuisance for the economy, arguing that it implies a higher level of taxation and distorts economic decisions.

This literature offers several possible explanations for the long lasting effects of colonialism on inequality that we advocate. Credit market imperfections and redistributive issues are certainly part of the economic environment in third world countries. These and other features could have "trapped" countries in the high inequality state in which they found themselves at the end of the colonization era.

\section{Colonization and European settlements ${ }^{6}$}

Table 1 presents the number of European settlers as a percentage of total population in the colonies. Our data comes from two main sources: Etemad (2000) and McEvedy and Jones (1978), supplemented in a few cases by other sources ${ }^{7}$.

As can be seen, we have classified all colonies into three groups according to the importance of European settlement. Some countries have been put in an "intermediate" level, between Settler and Peasant Colonies.

\section{$2.1 \quad$ New Europes}

The first and most homogeneous group is the one labeled "New Europes". In these countries the autochthonous population was almost entirely eliminated through diseases and wars. With the exception of the United States, where a minority of black Africans was brought as slave workers, almost all inhabitants were of European origin by the end of the colonial period.

The temperate climate of these countries, where "cash crops" like sugar could not be produced, together with the absence of autochthonous laborers greatly influenced the distribution of land - and thus of income - in them. Except for the southern United States, the regime of big plantations that characterized other regions was absent from these colonies. Instead, land was available in important quantities for European immigrants and the family farm was the typical unit of production. The average family farm in the northern

\footnotetext{
${ }^{6}$ This section borrows from Waites(1999), Etemad(2000), Bairoch(1997), Maddison (2001) and Enciclopaedia Britannica among others.

${ }^{7}$ Our values are very similar to those given in Appendix Table A5 of Acemoglu et al. (2001). Their numbers come mostly from McEvedy and Jones (1978).
} 
United States in the early XIXth century was over 100 acres (Maddison 2001). This, together with the relative richness in human capital of these settlers, assured most of them a high income per capita.

It is then natural to assume that inequality levels were not particularly high in these countries in colonial times. Whatever makes these countries more or less unequal today (the United States, for instance has one of the highest levels of inequality among industrial countries) is probably not directly related to their colonial experience.

\subsection{Settler Colonies}

"Settler Colonies", which we formally define as the countries where Europeans constituted between 10 and 30 percent of the colonial population, present a larger diversity. Although many aspects set the colonies of this group aside, we can identify two common denominators among them that are particularly important for our argumentation. First, the European minority was able to appropriate for themselves most of the land and mining resources in these countries, thus creating a very disproportionate income distribution. Second, independence in these countries was done by Europeans descendants and, we should add, for European descendants. This implied that the privileges that this group had obtained during the colonial period were not to be removed with the change of political status. If anything, European descendants were freer to impose their views and secure their advantages since they did not need to accommodate to the orders of the metropolis anymore.

Let us review the different colonies that can be included in this group, noting both the differences and similitudes among them. As Table 1 reveals, a majority of them can be found in today's Latin America and the Caribbean. A first set of countries would be the sometimes called "sugar islands", formed by the Greater and Lesser Antilles. The autochthonous population of these countries completely disappeared a few decades after the Europeans' arrival. These last ones decided to transform the islands into the world's supplier of sugar, the most important cash crop of the time ${ }^{8}$. Most European countries with colonial ambitions owned at least one island in the region: Spain (Cuba, today's Dominican Republic, Puerto Rico), England (Jamaica, Barbados, Antigua, Dominica, Tobago), France (Guadalupe, Martinique, Haiti), Holland (Curaçao, Aruba) and even Denmark (the Virgin Islands). Production in these colonies was based on slave labour. A large number of black slaves was imported from Africa all the way through the XIX century to work in sugar

\footnotetext{
${ }^{8}$ Sugar was by far the most important product of these countries. Other crops, like tobacco, played minor roles.
} 
plantations run by a European minority. Even tough it can be argued that the absolute income of African slaves was not lower than the one they could have expected in Africa (because they constituted a valuable investment for their owners so they did wanted to keep them able to work effectively), there can be no doubt about the extreme inequality prevailing in a society where a majority of the population is enslaved.

A major colonial power absent from the Caribbean was Portugal; but this was more than compensated by their most precious colony, which from the 16th century also specialized itself in sugar production: Brazil. Just as the much smaller territories of the Caribbean, Brazil also received several millions of slaves through its three centuries of colonial history. Most of them came to the northeastern region, where sugar plantations were located. In the 18th century mining became preponderant in the Brazilian economy but the distribution of income in this activity was as unequal as the one prevailing in the plantations.

The rest of Latin America constituted the gross of the Spanish Empire. The center of this Empire where the two rich mining regions of Mexico and today's Peru and Bolivia. These were also the most heavily populated areas of pre-colonial America, so that the autochthonous population continued to be important even after the large decline in its number that followed the conquest. This labor force was used by Spanish settlers in the silver mines and their rights were not much better than those of the slaves in other parts of the continent. In the area of the ancient Inca empire, for instance, the recruiting of workers by force was one of the privileges accorded to the Spaniards by the crown. Outside the mining heartlands agriculture was the main activity in Spanish America. This was not export-driven agriculture, like in northeastern Brazil and the Caribbean, but rather agriculture whose aim was to render Spanish America, and particularly its ports and cities of the mining regions, self-sustained in what concerns food. The typical production unit in these regions was the haciend $a^{9}$, a large landed estate belonging to a European settler where laborers (typically Indians) were de facto tied to the land by a series of debts incurred with the landlord. When the productivity of the silver mines of Mexico and the Andes declined in the 17th century, the haciendas became increasingly self-sufficient.

Unlike their counterparts in the northern side of the Continent, European settlers in Spanish America didn't came to work the land themselves. Their

\footnotetext{
${ }^{9}$ In Argentina the name of estancia would rather be used, while in Brazil we would talk of fazenda. The main difference between the Spanish America's hacienda and the plantations of the Caribbean was that the former produced a large range of agricultural and even manufactured goods while the last ones were specialized in one or few products for exportation.
} 
aim was to obtain either a mining concession or the right to a large piece of land that, through the work of Indians, would assure them a considerable wealth.

The descendants of these settlers formed the social class that was to achieve the independence of the nations of Spanish America. The criollos, name given to the people of European race born in America, furnished not only the intellectual and financial resources needed to achieve independence; they also formed the armies and fought the battles. Indians were very much outside of the whole struggle, the benefits of independence were not intended for them. It should then come as no surprise that the privileges of the criollos were maintained or reinforced after independence. The securing of the status quo was one of the reasons behind the independence wars.

Many similarities can be found in another colonized region where Europeans formed an important minority: South Africa. Even tough Europeans started to settle in the region as early as 1652, the Union of South Africa was created only at the beginning of the last century. The white population was constituted of two groups of similar size: the British and the Afrikaners, descendants of the early Dutch and German settlers. The British were dominant in the Cape region, where they controlled maritime routes, and British companies had obtained monopoly rights over the mining resources of the country, which included the world's richest gold and diamond mines. These mines employed black Africans in great numbers, the salary of a black worker being 9 times lower than that of a white one ${ }^{10}$. Afrikaners dominated the agricultural sector and as their number increased they concentrated most of the arable land in their hands at the expense of black Africans. This trend became law when in 1913 the Natives Land Act defined 8 percent of the land as "reserves" and prohibited the acquisition of land by Africans outside of them. The land policy was complementary with the interest of the mining companies: landless peasants had no choice but to look for work in the mining companies. So very much like in the Latin American case, mines and land together with political power were controlled by the European minority, giving rise to an extremely unequal society.

The situation was similar but less extreme in the colonies north of South Africa: today's Zimbabwe, Zambia and Malawi. The more we advance north the smaller the number of white settlers the region received and therefore the least effective their control on the country's resources. While in Zimbabwe white settlers did obtain from the British the right of self government, the less

\footnotetext{
${ }^{10}$ See "History of South Africa", Encoclopaedia Britannica. 2004
} 
numerous ones in Zambia and Malawi were directly governed by the British crown, who was more concerned with the well-being of Africans if only for reputational reasons. Zimbabwe adopted in 1930 a law similar to the one mentioned above for South Africa giving most of the land to the white minority.

The other important aspect in which the South African experience reminds that of Latin America is the fact that political power passed from the colonial power to the European descendants with independence. In South Africa this was not the result of a war but rather a steady process that progressively transferred all the government's prerogatives to the local elite. Once this process was achieved, the sort of the black Africans only worsened. With the adoption of the set of policies known as apartheid inequality was assured to last for a long time.

The postcolonial period in the other British colonies in the region is also greatly determined by the importance of European settlements. While in Zambia and Malawi Africans seized the power right from the early 1960s, the larger white minority of Zimbabwe managed to keep control of the land until the African based movements overthrew them in 1980.

The last region that can be included among our "settler colonies" is today's Algeria, and to a lesser extent Tunisia and Morocco. The migration of European settlers to Algeria was done together with large-scale confiscation of land belonging to Arabs. These last ones were forced to migrate to marginal lands which caused an important reduction of food production and even some famines. Thus we observe some of the elements characterizing colonies of important European settlement. A major difference with respect to South Africa or Latin America is that independence was achieved in Algeria by the autochthonous majority, at the cost of a destructive war. The white minority left the country after its independence.

We conclude that the colonial and post colonial experience of our "settler colonies" had many points in common. The accumulation of land and mining resources by the white minority during colonial times was reflected in the distribution of income. These settlers later obtained independence from the colonial power by war or by decree and worked to secure their status. Universal voting rights, public education and health were all slow to spread to the autochthonous population while the elite benefited from them at an early stage $^{11}$. All these factors assured that the initial high level of inequality of these countries was maintained over time.

\footnotetext{
${ }^{11}$ For an account of the process of extension of the franchise and of public schooling in the Americas see Engermann and Sokolof (2002).
} 


\subsection{Peasant Colonies}

Under this category we will place all colonies where the Europeans constituted only a very small minority, usually less than 1 percent of the population. These Europeans were typically not landowners or miners but rather administrators or tax collectors. This is easily the largest and most heterogenous of our three groups, and generalizations about its characteristics are more problematic. Still, we believe that in a majority of countries some common features can be identified, features that set the experience of these countries aside from those of the preceding groups. First, the appropriation of land by the white minority was small or in any case well below what could otherwise be observed in settler colonies. This does not mean that European-run plantations were absent from these colonies, they existed in many of them, but simply that the amount of land they controlled was limited by the reduced number of settlers.

Europeans certainly brought many changes with them but the pressure on the mass of the population that they exercised was not necessarily higher than what these countries knew under local rule. Tax revenues and the commerce of cash crops were the two main sources of revenue for the European powers in these colonies. This meant that a well functioning colonial economy would be in the interest of the colonizers. In general some parts of the autochthonous population was able to benefit with the colonial regime while others suffered. People employed as middle men by Europeans, as well as those related to commerce could take advantage of new possibilities. In addition, the colonial government demanded a large range of services that could only be supplied by the local population. On the other hand, many peasants suffered from high tax rates and in some cases were forced to work in the state's plantations or building public infrastructure.

A second main characteristic is that after independence political power passed from the European power to the autochthonous population, never to the European settlers as in the cases seen above. Thus, even tough the post colonization governments could put in place right or wrong policies, they were in general not captured by a racially differentiated minority regarding all the country's resources as their own.

Below we provide a picture of the most important countries in this group stressing the points just mentioned.

Let us begin with the most populated colonies of Asia and Africa; namely the British India (which included today's India, Pakistan and Bangladesh) and Nigeria. These two countries had in common that expropriation of land by Europeans was practically negligible. In Nigeria, as in many other colonies of West Africa, any attempt of European settlement was discouraged and even a 
law was made to forbid them from acquiring any land in 1917 (compare with South Africa, also a British colony, where four years earlier another law also forbid the acquisition of land but to the Africans). In Nigeria, as in Ghana or the Ivory Coast, the colonial power specially developed the commerce of tropical products like cacao, peanuts and palm oil. This commerce was done directly with local producers, who could benefice from it and became small entrepreneurs.

In a similar way, British did not take for themselves important land areas in India, plantations were rather rare. Instead they taxed the possession of land, just as in the Moghul empire. While this tax produced considerable revenues, one cannot say that the British were absorbing a large part of Indian GDP. According to Maddison (2001), the part of Indian national income after taxes that went to the British was around 5 percent, surely much higher than their part in total population of about $0.05 \%$ but still relatively modest at the aggregate level.

A different approach was used by the Dutch in today's Indonesia. A policy known as the "Cultivation System" was the landmark of Dutch rule during the 19th century. Under this system a fifth of all peasants' arable lands were to be destined to export crops. The production of these lands served to pay government's taxes. In the middle of the 19th century half of the colony's population were concerned by this policy. The Cultivation System was a success from the Dutch's point of view, Indonesia became one of the world's most profitable colonies. In what concerns the effect on the local population, opinions differ. Although it is true that agricultural production increased considerably, local peasants could hardly benefit from the overseas trade which was controlled by the colonizers. From the late 19th century onwards, the Cultivation System was progressively abandoned in favor of private enterprise. European investors were allowed to produce in the agricultural sector, with the provision that they could only lease, not buy, land from local populations. The views on colonization had changed in the Netherlands and the future of the autochthonous people was taken into account.

In the rest of the colonial world large plantations run by Europeans were rather the exception than the rule. There are of course some examples like Sri Lanka, with the production of tea, and Malaysia, with the production of tin and rubber, where European plantations came to dominate the economy; but these cases are a minority. The regions where European presence was more limited and economic production stayed largely in the hands of local people are larger and more numerous: the Sahel, West Africa, East Africa (except 
some regions in Kenya), Indochina. The Congo region constitutes a separate case. Private companies received concessions from the estate to exploit these countries' resources and were given the right to impose labour coercion. This was probably the African region that suffered the most from European colonialism; famines and demographic regression were the final consequences of an exploitation of African labour taken to the extreme.

To summarize, in this section we have argued that colonial experiences can be classified into three types: New Europes, Settler Colonies and Peasants Colonies. The group to which a particular ex colony belongs is determined by the percentage of European settlers in total population at colonial times. Of these three groups, one presents two characteristics that are particularly relevant for a study of inequality. This is the one of Settler Colonies, where Europeans formed an important minority of the population. In these countries colonization brought an extreme concentration of productive assets, mainly land and mining resources, into the hands of European settlers. Moreover, independence from the metropolis was achieved precisely by these settlers; and one of its aims was to maintain the elite's political and economic preeminence in these countries. This is why these colonies became very unequal societies and stayed like that until today.

In the other two sets of countries the effects on inequality where less dramatic and not necessarily negative. Even if Europeans had as only goal the extraction of as much income as possible from their Peasants Colonies (and we are not claiming that this was the case), their presence in these countries was simply not important enough to assure them a very large part of the colonies' GDP. Only in the few cases where Europeans resolved themselves to a systematic use of violence could such a goal be achieved. Otherwise, Europeans used the more conventional approach of taxing; leaving the economy in the hands of the autochthonous and eventually allowing them to benefit from the new opportunities. Furthermore, in these countries we don't observe systematically that a particular racial minority seized all political power after independence (although, to be sure, this is far from a guarantee for good government).

In the next section we will use data on inequality to test for a positive relationship between European settlement and inequality levels among all excolonies except the "New Europes".

\section{Empirical results}

\subsection{Methodology, assumptions and results}


In this section we use a comprehensive set of data to test the link between inequality and colonialism that we hypothesized above.

The measure of inequality that we will use in most regressions is the Gini coefficient, a measure for which we have a total of 1062 observations distributed among 139 countries in the period from 1947 to 1998. In order to assure that our results hold for other inequality measures we also use the ratio of the share of income of the richest to the poorest quintile of the population. This measure, while also popular, contains less information than the Gini coefficient, which considers the whole income distribution and not just the extremes. The data on inequality is taken from the "World Income Inequality Database" (WIID) from the United Nations (see U.N. 2000); which has been formed by expanding the Deininger and Squire (1996) data set. We have selected from this data set the observations that cover both the whole population and the whole area of the country and that are characterized as "Reliable data" (in opposition to some observations which are called "less reliable data"). For each country we have formed the longest possible series of observations, the source of the observations changes for any given country over time.

The Gini coefficients as they are given in the WIID are not directly comparable since they are calculated from different concepts of income (like expenditure, gross income or net income) and because they are referred to different income recipients units (households or persons). This is an important factor since the distribution of, say, net income differs considerable from that of gross income. We deal with this problem in the same way as $\mathrm{Li}$, Squire and Zou (1998) (and many others after them) did : we include a dummy variable for these characteristics in each one of the regressions. We use three dummy variables to control for the effect of having as type of income respectively expenditure, net income or monetary income instead of gross income. We also include two dummy variables to control for the effects of having as the income recipient unit the individual or the "Household or Family equivalent" instead of the Household or the Family.

The basic regression we are running is the following:

$$
\text { Ineq }_{i, t}=\alpha_{0}+\alpha_{1} \text { ESet }_{i}+\alpha_{2} \text { NewEurope }_{i}+\sum_{j=1}^{J} \beta_{j} X_{i, t}+\sum_{k=1}^{5} \gamma_{j} D_{i, t}+\varepsilon_{i, t}
$$

where Ineq $_{i, t}$ is the Gini coefficient of income (or the ratio of income of the highest and lowest quintiles) , ESet $t_{i}$ is the percentage of Europeans in total population in colonial times for all colonized countries except the New Europes, NewEurope ${ }_{i}$ is a dummy for these colonies, $X_{i, t}$ is a list of control 
variables that have been used in many different studies of inequality and $D_{i, t}$ are the dummies controlling for the different types of data.

The list of control variables is the following (see the Appendix for data sources):

- GDP per capita and its square, to search for a "Kuznet's curve".

- The amount of credit to the private sector by banks and other financial institutions as percentage of GDP. This is a measure of the development of the Financial Sector.

- Secondary school (gross) enrollment ratios in 1970. When the regression includes this variable the sample starts in 1970, so that this variable can be considered as the initial secondary school enrollment.

- The percentage of the population between 40 and 59 years old ${ }^{12}$.

- The inflation rate (mean over the last 5 years, inflation in consumer's prices).

- Arable land per capita, in hectares.

- Measure of Political rights (mean over the last 5 years).

- Dummy for communist countries.

- Dummies for Latin American and sub-Saharan countries.

- Dummies for the identity of the colonizing power.

The assumption we make about equation (1) is that there is no endogeneity problem concerning the percentage of European settlers and the dummy for New Europes. This requires that the number of Europeans that settled in the colonies were not a function of inequality levels today or of any variable affecting inequality today that is omitted in equation (1). This assumption can be put into question. In particular, one might want to think of a common factor for both the European settlements and the level of inequality that is not included among our list of regressors. A candidate for such a factor would be the climatic characteristics and the natural endowments of the country. If we think of sugar cane production for instance, one could argue that a warm

\footnotetext{
${ }^{12}$ This variable was used by Higgins and Williamson (1999) in their study of the determinants of inequality. The logic of their argument is the following: it is well known from labor economics that wages increase with age, and this is a source of inequality. If we admit that the labor supply of persons from different ages are imperfect substitutes, then we can argue that if the number of people in a given age group increases then the wage of the people in that group will decrease (by an excess supply argument). This means that if the percentage of people in the age group with the highest wage increases then income inequality should decrease. The age group with the highest wages is precisely the 40 to 59 years old. We'll call this variable "Mature".
} 
climate and appropriate land is the ultimate cause for having a sugar producing economy -which creates an unequal distribution of income- and a large number of European settlers - who would be attracted by the prospective profits of this activity. In this sense, the argument would go, European settlement is not the ultimate cause of high inequality since this would have existed anyway given the country's propensity to sugar cane production.

The above argument seems flawed to us. The problem lies in the fact that climate and natural endowments will not imply any given type of economic activity and distribution of income without human intervention. It turns out that the history of sugar cane production is revealing on this area. In the century leading to the discovery of the Americas by Columbus, Spain and Portugal had progressively expanded their areas of influence into the Atlantic and northern Africa; conquering several islands like Madeira (Portugal) and the Canary islands (Spain). These possessions had an adequate climate for sugar cane production and indeed, Iberians started to create plantations and to import African slaves into them ${ }^{13}$. This process was aborted when sugar production shifted to the newly discovered colonies of the Americas, and Madeira and the Canary islands eventually became populated almost completely by Europeans. Thus, it is the actions of men - and more specifically of European settlers that set these islands apart from their counterparts in the Caribbean and that constitute the ultimate cause of their income distribution.

Even tough we believe that our assumption of no endogeneity problem concerning the ESet variable is justified, we will try to control for the type of effects mentioned in the last paragraph by including a dummy variable that takes the value of 1 for the colonies that used slave force. This variable is closely related to some key climatic aspects of the country, namely the suitability of developing sugar cane or tobacco exploitations. Moreover, this variable will be useful to ensure that the percentage of European settlers is not just "picking up" the effect of being a former slave colony.

Another issue is the fact that our variable for European settlers is very probably measured with error. However, this should not be a source of worry since it produces only a bias towards zero in the estimates. As we will see, the coefficients we obtain for the ESet variable are large and significant anyway, so if we could observe this variable without measurement errors our conclusions would only be stronger.

Endogeneity problems might exist for our control variables. One can be

\footnotetext{
${ }^{13}$ On this subject see Phillips and Phillips (1992).
} 
especially suspicious about the variable measuring the development of the financial sector, the ratio of credit to GDP. As Clarke et al. (2002) have noted, reverse causality is a concern with this variable since it is natural to think that in a less unequal society more people will have access to the financial system. In other words, the amount of credit would depend on inequality. Since this can potentially bias our result we will also consider an instrumental variables estimation where, as in Clarke et al. (2002), we use the La Porta et al. (1998) set of dummies identifying the origin of the country's legal system as an instrument for the development of the financial sector.

Our first results are given in Table 2. This series of regressions strongly supports our hypothesis about the effects of European settlements on inequality. As can be seen, the regression that includes as explanatory variables only the percentage of European settlers and a dummy for the "New Europes" manages to explain 50 percent of the variation of the endogenous variable. Moreover, as we progressively include all our control variables the coefficient on the percentage of European settlers remains significant at the $1 \%$ level and its value stabilizes at a level between 0.35 and 0.40 . This value implies that a colony where white settlers constituted $25 \%$ of the population would have a Gini coefficient about 10 points higher than one where European settlements were negligible. This is a very large effect, remember that the difference between low inequality countries in Europe and high inequality ones in Latin America or Africa are in the 15 to 20 Gini points range. The dummy for the "New Europes" is always small and becomes statistically non significant once several controls are added. This is also in accordance with the description of the colonial experience of these countries.

On the last four columns of this table we rerun some regressions using the instrument for the development of the financial sector mentioned above. As we can see there are almost no changes in the estimated coefficient so our conclusions remain the same.

In Table 3 we consider the same regressions of Table 2 but instead of using as explanatory variable the percentage of European settlers we include two dummy variables: one for Settler colonies and one for Peasant colonies ${ }^{14}$. The

\footnotetext{
${ }^{14}$ To create these two dummy variables we have separated all colonies (besides the New Europes) in two groups: those where the percentage of Europeand settlers was above $10 \%$ and those where it was below this limit. Thus, in terms of our discussion in section 2, we have included the colonies with an "intermediate" number of European settlers (between 1 and $10 \%$ ) among the Peasant colonies. To ensure that this is not a problem we have rerun the regressions using $4 \%$ instead of $10 \%$ to create the dummies. The results go unchallenged (not shown in the table).
} 
results are very similar to those in Table 2 . The coefficient on settler colonies is always significant at the $1 \%$ level and its value is large, ranging from 16.91 when no controls are added to around 8 when controls are present. The coefficient on peasants colonies takes much lower values and it is not always statistically significant. The coefficient on the "New Europes" is, as in the previous table, close to zero and usually non significant. As before, the IV regressions give essentially the same picture.

Table 4 repeats the regressions of Tables 2 and 3 once again, this time changing the dependent variable for the ratio of the share of income of the richest to the poorest quintile of the population. Once again, the statistical significance of the variable measuring the percentage of European settlers in total population is always strong. Since the ratio of the richest to the poorest quintile is a more volatile measure than the Gini coefficient the regressions that use this variable have a somewhat smaller explanatory power. But the fact is that our central hypothesis continues to be verified when we measure inequality in another way.

In what concerns our control variables several points can be stressed. First, most coefficients look fairly stable along different regressions, taking similar values as we add more variables. Being a communist country has a strong negative effect on inequality in all regression where the dependent variable is the Gini coefficient; but its statistical significance is lost when we use the quintiles ratio instead. Two variables that are consistently associated with lower inequality are initial secondary school enrollment and the fraction of the population in the 40 to 59 years old range; confirming our priors about their effect. On the other hand, the amount of credit for the private sector - which stands for the development of the Financial Sector - does not have the sign one would expect. Its coefficient is positive, meaning that a more developed Financial Sector is associated with higher, not lower inequality. When we instrument this variable with the dummies for the origin of the legal system the coefficients are somewhat smaller and can become negative, but no clear conclusion can be drawn.

Also with a positive and statistically significant coefficient are the Political Rights variable and the Arable land per capita. Inflation does have the right (positive) sign but its coefficient is statistically non significant. Finally, the GDP per capita is not statistically significant while its square is, and their effect corresponds to a "U-shaped" relationship between inequality and income, thus rejecting "Kuznet's hypothesis".

Perhaps a more pertinent way to look at our results is to compare the effect 
that a change in our explanatory variables would produce on inequality. This is done in Table 5, where we have calculated the change in the Gini coefficient following a one standard deviation change in every variable (except for dummy variables and for those were we noted otherwise). The values in this table were obtained using the coefficients estimated in the last OLS regression of Table 2. The main message of this table is that there are two variables whose effects on inequality are clearly above the rest. These are the percentage of European settlers on colonial times and having a communist regime. Having a quarter of its population of European origin instead of zero can be associated with a Gini coefficient 9 points higher, while communist countries can be expected to have an inequality level 11.85 points lower ceteris paribus. For all other variables the effects are considerable lower, all but secondary school enrollment are below the 2 Gini points mark.

We believe that Table 5 conveys an important message. The main causes behind large differences in inequality between countries are to be found in drastic historical events that dramatically reshaped the social and economic structure of the countries. Two of these events were colonialism (when accompanied by an important inflow of European settlers) and communism. Other type of factors like education, inflation or political rights, might be useful explaining the (comparatively smaller) changes in inequality within a country over time but they are less relevant to the question of why some countries are much more unequal than others.

\subsection{Robustness checks}

We will submit our results to three further robustness checks. Starting from equation (1) with all control variables, we will include by turn three sets of dummy variable whose effect could be at the root of the large and significant coefficient of our ESet variable. The results are presented in Table 6 .

The first column of this Table includes dummies for both Latin American and sub-Saharan African countries. It could be argued that our variable for European settlement is just picking up some "special" features of these two regions. The data does not support this idea, the coefficient on ESet remains highly significant and even larger than in some of the regressions in Table 2. The dummy for Latin America is small and non significant while the one for sub-Saharan Africa is large and statistically significant. This reflects the fact that the explanation we provide in this paper does a good job in explaining high inequality in Latin America but less of a good one in what concerns Africa. While the southern cone of the African continent seems to correspond quite well to the group of heavily settled and highly unequal countries, the 
picture is more contrasted in the rest of the continent. Many Peasant colonies in Africa have, as we would predict, relative low level of inequality: the Gini coefficient in Ghana is around 33, in Uganda 39 and in Rwanda only 29. But other countries that received comparably low numbers of European settlers show much higher levels of inequality: in Gabon, Kenya and Guinea Bissau the Gini coefficient is close to 60 . We note simply that we never intended to offer an exclusive explanation of inequality around the world. Other aspects must be in place in these cases, like the pre-colonial level of inequality of these societies, for which we cannot control for.

The second column of Table 6 introduces dummies for the identity of the colonial power. As we can see, the dummies for Spanish, French and British colonies have all relatively small effects and their coefficients are not significant while the coefficient on the percentage of European settlers is almost unchanged. This supports the general view on colonialism that this paper takes, namely that the determinant aspect of the colonial experience concerning inequality is the presence or absence of numerous European settlers, and not whether the country was colonized by Spain instead of England. A similar conclusion is expressed in Acemoglu et al. (2001), who also find that the coefficients on dummies that identify the colonial power turn out to be non significant.

The last column of Table 6 includes a dummy for the colonies where slaves were imported in great numbers. This group includes the Caribbean countries, Brazil and the United States. As we discussed before, one might be tempted to believe that it is the fact of being a slave colony, and not the fact of having a large number of European settlers, that is behind our results. Moreover, the dummy for slave colonies might also control for some climatic characteristics that have been left out of the regressions. The regression shows that the ESet variable is still significant at the $1 \%$ level and the coefficient stays in the same range as those obtained in Table 2. Thus, the effect of being a Settler colony goes beyond the fact of having developed slave plantations or not. We also notice that the dummy for slave colonies is significant and its effect is important. As we could have expected, a country marked by a history of slavery will have typically higher levels of inequality.

Another potential concern is that we have not counted as colonized countries any of the republics that formed the ancient Soviet Union. To be sure that this is not biasing our results we have repeated our regressions excluding all the former republics of the Soviet Union except Russia, Ukraine and Belarus (which can hardly be qualified as regions colonized by the Russian empire). The estimated coefficients don't suffer any major change so the conclusions 
continue to hold (not shown in the table).

\section{Conclusions}

Our paper's main point is that Colonial History is a major explanatory factor behind today's large differences in inequality among the world's countries. We have reviewed the different colonial experiences of the last five centuries and have classified them in 3 broad categories. Of these three, we argued that one clearly produced and sustained highly unequal societies. This highinequality group is the one where colonialism brought into the country an amount of European settlers whose number was considerable but still inferior to that of the local population. This minority was able to concentrate most of the countries' income in their hands, mainly by excluding the rest of the population from owning land or mining resources. Moreover, and with the exception of Algeria, it was this minority who took all political power once these countries became independent. This allowed high inequality to remain a characteristic of these countries up to our times.

We believe that the empirical evidence strongly advocates our view. The number of European settlers as a percentage of total population has clearly a statistically significant and an economically substantial effect on inequality. The effect is robust to the inclusion of a large number of control variables and dummies taking into account the identity of the colonizer and the region of the world where the country is located.

One might be tempted to infer, given the above conclusions, that European settlement was a negative phenomenon for the countries where it took place (excluding the four cases of Australia, Canada, New Zealand and the U.S.) since the society that came out of these countries was highly unequal. In addition, one could add that such a message is in contradiction with the results of Acemoglu et al. (2001), where more European settlements have rather positive consequences since they are associated with better institutions and thus with a higher level of GDP per capita.

My view is that we should not try to draw simplistic conclusions out of a complex issue like the effects of colonialism. Furthermore, there is no contradiction whatsoever between the fact that settler colonies became highly unequal and the one that these same colonies achieved a higher level of production per capita. This relative economic success was precisely the resultant of the Europeans settlers' growth record. By their cultural background they were able to put at least partially in place the technology and institutions that made the economic superiority of Europe and the New Europes. 
It should also be kept in mind that the higher inequality of the former settler colonies does not imply that the poorer majority of these countries is less well-off in absolute terms than the people from the less unequal peasant colonies. Inequality is a relative concept and it doesn't inform us about the absolute level of GDP per capita. There exists a trickle-down effect in the former settler colonies since the rich minority demands and consumes many services provided by the poor and in this way makes them profit at least in part of their well being. If this effect is strong enough then it might be better to be poor in a former Settler Colony than in a former Peasant Colony, at least in what concerns absolute levels of income.

A final comment on the "Kuznets' hypothesis" is also in order. Our paper tells us that the Colonial experience of developing countries is of the highest relevance when analyzing inequality issues while the level of development, measured by an indicator like GDP per capita, is not. The empirical record refutes the "inverted-U" relationship between inequality and income while it supports the one between inequality and European settlement. It might then come as a surprise that some intellectual support for the ideas we present here can be found in the same paper of 1955 where Simon Kuznets formulates his famous hypothesis. Kuznets had certainly noted that his analysis was not appropriate for every country in the world and that there was something particular about some colonized regions. On page 21 of Kuznets (1955) we read that he is excluding of his analysis countries that are characterized by "... large native populations with small enclaves of nonnative, privileged minorities, e.g. Kenya and Rhodesia, where income inequality, because of the excessively high income shares of the privileged minority, is appreciably wider than even in the underdeveloped countries cited above." The problem is that this case of a small enclave of nonnative, privileged minority is far from being an exception and concerns an important number of developing countries in the world. Kuznets, after all, had seen it right. 


\section{References}

[1] Acemoglu, D., S. Johnson and J.A. Robinson, 2001, The colonial origins of comparative development: an empirical investigation, American Economic Review 91, 1369-1401.

[2] Acemoglu, D., S. Johnson and J.A. Robinson, 2002, Reversals of fortune: geography and institutions in the making of the modern world income distribution, Quarterly Journal of Economics 117, 1231-1294.

[3] Ahluwalia, M., 1976, Inequality, poverty and development, Journal of development economics 6, 299-341.

[4] Anand, S. and S.M.R. Kanbur, 1993a, The Kuznets process and the inequality-development relationship, Journal of development economics 40(1), 25-52.

[5] Anand, S. and S.M.R. Kanbur, 1993b, Inequality and development. A critique, Journal of development economics 41(1), 19-43.

[6] Bairoch, P., 1997, Victoires et déboires (Gallimard).

[7] Beck, T., A. Demirgüç-Kunt and R. Levine, 2000, A new database on the structure and the development of the financial sector, World Bank Economic Review 14(3), 597-605.

[8] Bertocchi, G. and F. Canova, 2002, Did colonization matter for growth? An empirical exploration into the historical causes of Africa's underdevelopment, European economic review 46, 1851-1871.

[9] Birmingham, D., 1995, The decolonization of Africa (UCL Press Limited).

[10] Bourguignon, F. and C. Morrision, 1998, Inequality and development: the role of dualism, Journal of Development Economics 57, 233 - 257.

[11] Bourguignon, F. and C. Morrision, 2002, Inequality among world citizens: 1820 - 1992, American Economic Review 92 (4), 727 - 744.

[12] Bourguignon, F. and T. Verdier, 2000, Oligarchy, democracy, inequality and growth, Journal of Development Economics 62, 285-313.

[13] Clarke, G., L. C. Xu and H. Zou, 2002, Finance and Income inequality: test of alternative theories, mimeo.

[14] Deininger, K.and L. Squire, 1996, Measuring income inequality: a new data-base, World Bank Economic Review 10(3), 565-591.

[15] Deininger, K., and L. Squire, 1998, New ways of looking at old issues: inequality and growth, Journal of Development Economics 57, 259 - 287.

[16] Engerman, S.L. and K.L. Sokoloff, 2002, Factor endowments, inequality and paths of development among new world economies, NBER working paper 9259.

[17] Etemad, Bouda, 2000, La possession du monde: poids et mesures de la colonization, Brussels: Ed. Complexe. 
[18] Fieldhouse, D.K., 1981, Colonialism 1870-1945. An Introduction (Weindenfield and Nicolson, London).

[19] Galor, O. and J. Zeira, 1993, Income distribution and macroeconomics, Review of Economic Studies 60, 35-53.

[20] Gastil, R., various years, Freedom in the world (Westport, Greenwood press).

[21] Grier, R. M., 1999, Colonial legacies and economic growth, Public choice $98,317-335$.

[22] Higgins, M. and J. Williamson, 1999, Explaining inequality the world round: cohort size, Kuznets curves and opennes, NBER working paper 7224 .

[23] Kuznets, S., 1955, Economic growth and Income inequality, American Economic Review 45, 1 - 28.

[24] Landes, D. S., 1998, The wealth and poverty of nations (Abacus).

[25] Li, H., L. Squire and H. Zou, 1998, Explaining international and intertemporal variations in income inequality, The Economic Journal 108, 26 - 43.

[26] Phillips, W. D. and C. Rahn Phillips, 1992, The worlds of Christopher Columbus, Cambridge University Press.

[27] Reinhard, W., 1997, Petite histoire du colonialisme (Ed. BELIN, Paris).

[28] UN / WIDER - UNDP World Income Inequality Database, Version 1.0, 12 September 2000.

[29] Waites, B., 1999, Europe and the Third World (Macmillan).

[30] World Bank, 2002, World Development Indicators 2002. 


\section{A Data sources}

- Gini coefficients: WIID (World Income Inequality Database), U.N. (2000)

- Percentage of European settlers in colonial times: see Table 1.

- GDP per capita: World Bank(2002)

- Credit to the private sector as a percentage of GDP: Beck et al. (2000). This variable has been used in the study of inequality of Clarke et al. (2002).

- Secondary school (gross) enrollment ratios in 1970: World Bank(2002). Variable used by Li et al. (1998).

- Percentage of the population between 40 and 59 years old: U.S. census bureau and U.N. Demographic Yearbook (various issues). This variable was used by Higgins and Williamson (1999).

- The inflation rate (mean over the last 5 years, inflation in consumer's prices): World Bank(2002).

- Arable land per capita: World Bank(2002). Variable used by Bourguignon and Morrison (1998).

- Measure of Political rights: mean over the last 5 years of the score for "Political rights" given in the "Freedom in the World" yearly publication, Gastil (various years).

- All mentioned dummies: author's calculations. 
Table 1. Percentage of European Settlers in the Colonies

\begin{tabular}{|c|c|c|c|}
\hline$\overline{\text { Country }}$ & $\begin{array}{l}\text { European Settlers } \\
\text { as a percentage of } \\
\text { total population }\end{array}$ & Year & Source \\
\hline \multicolumn{4}{|c|}{$\begin{array}{l}\text { New Europes } \\
\text { (percentage of European } \\
\text { settlers higher than } 50 \% \text { ) }\end{array}$} \\
\hline Australia & 98.6 & 1913 & Etemad (2000) \\
\hline Canada & 98.1 & 1913 & Etemad (2000) \\
\hline New Zealand & 95.1 & 1913 & Etemad (2000) \\
\hline United States & 79.54 & 1760 & Etemad (2000) \\
\hline \multicolumn{4}{|c|}{$\begin{array}{l}\text { Settler Colonies } \\
\text { (percentage of Europeans } \\
\text { between } 10 \text { and } 30 \% \text { ) }\end{array}$} \\
\hline Mexico & 15.18 & 1800 & McEvedy and Jones (1978) \\
\hline Central America & 20 & 1800 & McEvedy and Jones (1978) \\
\hline Dominican Republic & 20 & 1800 & McEvedy and Jones (1978) \\
\hline Colombia, Venezuela & 20 to 25 & 1800 & McEvedy and Jones (1978) \\
\hline Ecuador, Peru, Bolivia & 30 & 1800 & McEvedy and Jones (1978) \\
\hline Paraguay & 25 & 1800 & McEvedy and Jones (1978) \\
\hline Brazil & 25 & 1822 & McEvedy and Jones (1978) \\
\hline Chile, Argentina & 21.42 & 1800 & McEvedy and Jones (1978) \\
\hline South Africa, Lesotho & 21.4 & 1913 & Etemad (2000) \\
\hline Algeria & 14.3 & 1913 & Etemad (2000) \\
\hline Trinidad and Tobago & 15 & & McEvedy and Jones (1978) \\
\hline Barbados & 14.56 & 1834 & Encyclopaedia Britannica \\
\hline \multicolumn{4}{|l|}{$\begin{array}{l}\text { Percentage of Europeans } \\
\text { between } 1 \text { and } 10 \%\end{array}$} \\
\hline Zimbabwe & 8.57 & 1953 & Etemad (2000) and E.B. \\
\hline Zambia & 3.07 & 1952 & Etemad (2000) and E.B. \\
\hline Malawi & 3 & 1900 & Acemoglu et al. (2001) \\
\hline
\end{tabular}




\begin{tabular}{|c|c|c|c|}
\hline Country & $\begin{array}{l}\text { European Settlers } \\
\text { as a percentage } \\
\text { of total population }\end{array}$ & Year & Source \\
\hline Tunisia & 7.9 & 1913 & Etemad (2000) \\
\hline Morocco & 3.1 & 1939 & Etemad (2000) \\
\hline Hong Kong & 4 & 1900 & Acemoglu et al. (2001) \\
\hline Singapore & 5 & 1900 & Acemoglu et al. (2001) \\
\hline Jamaica & 6.25 & 1800 & McEvedy and Jones (1978) \\
\hline Bahamas & 10 & & McEvedy and Jones (1978) \\
\hline Korea & 1.8 & 1913 & Etemad (2000) \\
\hline Taiwan & 3.9 & 1913 & Etemad (2000) \\
\hline \multicolumn{4}{|c|}{$\begin{array}{l}\text { Peasant Colonies } \\
\text { (percentage of European } \\
\text { settlers below } 1 \% \text { ) }\end{array}$} \\
\hline $\begin{array}{l}\text { India, Pakistan, } \\
\text { Bangladesh, Nepal }\end{array}$ & 0.1 & 1913 & Etemad (2000) \\
\hline Indonesia & 0.3 & 1913 & Etemad (2000) \\
\hline Vietnam, Cambodia & 0.1 & 1913 & Etemad (2000) \\
\hline Malaysia & 0.5 & 1913 & Etemad (2000) \\
\hline $\begin{array}{l}\text { French Colonies in } \\
\text { sub-Saharan Africa }\end{array}$ & 0.2 & 1913 & Etemad (2000) \\
\hline $\begin{array}{l}\text { British Colonies in } \\
\text { sub-Saharan Africa }\end{array}$ & 0.1 & 1913 & Etemad (2000) \\
\hline $\begin{array}{l}\text { Belgian Colonies in } \\
\text { sub-Saharan Africa }\end{array}$ & 0.1 & 1913 & Etemad (2000) \\
\hline
\end{tabular}

Note: : for Korea and Taiwan the number corresponds to the percentage of Japanese settlers. 
Table 2

Effectsof colonialismon inequality using the percentage of Eurpeansettlers.

\begin{tabular}{|c|c|c|c|c|c|c|c|c|c|c|}
\hline \multirow[b]{2}{*}{$\begin{array}{l}\text { Percentage of European } \\
\text { settlers }\end{array}$} & \multicolumn{6}{|c|}{ OLS } & \multicolumn{4}{|c|}{ IV } \\
\hline & $0.72^{\star * *}$ & $0.62^{* * *}$ & $0.44^{* * *}$ & $0.33^{\star * *}$ & $0.37^{* * *}$ & $0.36^{\star * *}$ & $0.43^{\star * *}$ & $0.33^{* * *}$ & $0.37^{* * *}$ & $0.36^{\star * *}$ \\
\hline New-Europes dummy & $-2.10^{\star * *}$ & $-3.17^{\star * *}$ & 0.24 & -0.42 & $-2.30^{*}$ & -1.07 & 0.27 & -0.40 & -2.30 & -1.05 \\
\hline Communist dummy & & $-8.47^{* * *}$ & $-10.02^{* * *}$ & $-8.77^{\star \star *}$ & $-10.30^{* * *}$ & $-11.85^{* * *}$ & $-10.12^{* *}$ & $-8.81^{* *}$ & $-10.30^{* *}$ & $-11.85^{\star * *}$ \\
\hline Private credit & & & 0.007 & $0.019^{* * *}$ & $0.023^{* * *}$ & 0.0 & -0.004 & $0.016^{*}$ & $0.023^{\star *}$ & -0.0004 \\
\hline $\begin{array}{l}\text { Secondary schooling in } \\
1970\end{array}$ & & & $-0.149^{* * *}$ & $-0.107^{* * *}$ & $-0.103^{* * *}$ & $-0.107^{* * *}$ & $-0.142^{\star * *}$ & $-0.106^{* * *}$ & $-0.103^{* * *}$ & $-0.107^{* * *}$ \\
\hline Mature & & & & $-0.48^{* * *}$ & $-0.46^{* * *}$ & $-0.34^{* * *}$ & & $-0.47^{\star * \star}$ & $-0.46^{* * *}$ & $-0.34^{* * *}$ \\
\hline Inflation & & & & $0.0057^{*}$ & $0.0052^{*}$ & 0.0050 & & $0.0055^{* *}$ & $0.0052^{* *}$ & $0.0050^{\star *}$ \\
\hline Arable land per capita & & & & & $2.81^{* * *}$ & $2.57^{* * *}$ & & & $2.80^{\star * *}$ & $2.56^{\star * *}$ \\
\hline Political rights & & & & & $0.39^{*}$ & $0.81^{* * *}$ & & & $0.39^{*}$ & $0.81^{* * *}$ \\
\hline GDP per capita & & & & & & -0.00017 & & & & -0.000175 \\
\hline GDP per capita squared & & & & & & $8.60^{*} 10^{-9} * * *$ & & & & $8.59^{*} 10^{-9} * *$ \\
\hline S a mple & $1947-1998$ & $1947-1997$ & $1970-1997$ & $1970-1997$ & $1977-1997$ & $1977-1997$ & $1970-1997$ & $1970-1997$ & $1977-1997$ & $1977-1997$ \\
\hline Countries included & 139 & 139 & 92 & 84 & 82 & 82 & 92 & 84 & 82 & 82 \\
\hline Number of obs. & 1062 & 1062 & 601 & 576 & 479 & 470 & 601 & 576 & 479 & 470 \\
\hline $\mathrm{R}^{2}$ & 0.50 & 0.54 & 0.66 & 0.68 & 0.70 & 0.72 & & & & \\
\hline
\end{tabular}

White heteroscedasticity-consistent standard errors

have been used. ${ }^{*},{ }^{* *}$ and ${ }^{* * *}$ denotes significance at

$10 \%, 5 \%$ and $1 \%$ levels. 
Table 3

Effectsof colonialismon inequality using dummies for each type of colony.

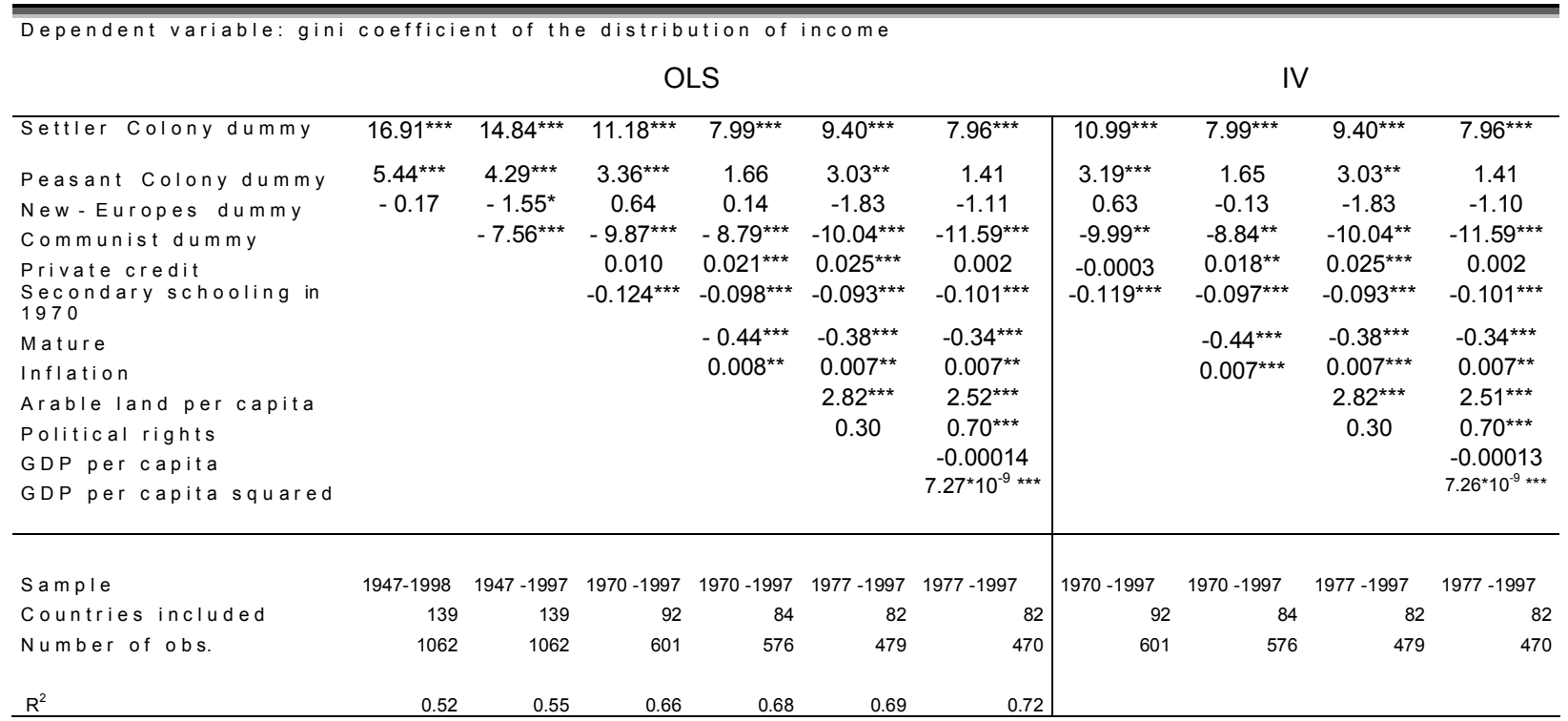

White heteroscedasticity-consistent standard errors

have been used. ${ }^{*},{ }^{* *}$ and ${ }^{* * *}$ denotes significance at

$10 \%, 5 \%$ and $1 \%$ levels. 
Ta ble 4

Effectsof colonialismon inequality. Measureofinequality: ratio of share of income of highest to lowest quintile.

\begin{tabular}{|c|c|c|c|c|c|c|}
\hline $\begin{array}{l}\text { Percentage of European } \\
\text { settlers }\end{array}$ & $0.39^{* * *}$ & $0.36^{* * *}$ & $0.25^{\star * *}$ & $0.19^{* * *}$ & $0.18^{* * *}$ & $0.18^{* * *}$ \\
\hline New-Europes dummy & 0.40 & -0.23 & $1.36^{*}$ & 0.75 & 0.23 & 0.38 \\
\hline Communist dummy & & $-3.34^{* * *}$ & -2.61 & -0.75 & -0.44 & -0.68 \\
\hline Private credit & & & 0.0062 & $0.017^{* * *}$ & $0.019^{\star * *}$ & 0.008 \\
\hline $\begin{array}{l}\text { Secondary schooling in } \\
1970\end{array}$ & & & $-0.071^{* * *}$ & $-0.028^{*}$ & $-0.041^{* *}$ & $0.045^{\star *}$ \\
\hline Mature & & & & $-0.36^{* * *}$ & $-0.35^{\star * *}$ & $-0.30^{* * *}$ \\
\hline Inflation & & & & $0.015^{\star * *}$ & $0.016^{* * *}$ & $0.015^{\star * *}$ \\
\hline Arable land per capita & & & & & 0.77 & 0.85 \\
\hline Political rights & & & & & -0.12 & -0.057 \\
\hline GDP per capita & & & & & & $7.60 * 10^{-5}$ \\
\hline GDP per capita squared & & & & & & $4.64^{*} 10^{-9}$ \\
\hline S a mple & 1947-1998 & $1947-1997$ & $1970-1997$ & $1970-1997$ & $1977-1997$ & $1977-1997$ \\
\hline Countries included & 118 & 118 & 77 & 70 & 70 & 70 \\
\hline Number of obs. & 669 & 669 & 366 & 347 & 283 & 278 \\
\hline $\mathrm{R}^{2}$ & 0.30 & 0.32 & 0.35 & 0.49 & 0.51 & 0.51 \\
\hline
\end{tabular}

White heteroscedasticity-consistent standard errors

have been used. *, ** and ${ }^{* *}$ denotes significance at $10 \%, 5 \%$ and $1 \%$ levels.

Dependent variable: ratio of share of income of highest and lowest quintiles. 


\section{Table 5}

Effects of explanatory variables on inequality.

\begin{tabular}{lc}
\hline Variable & $\begin{array}{c}\text { Increase in } \\
\text { the gini } \\
\text { coefficient }\end{array}$ \\
\hline $\begin{array}{l}\text { Percentage of European settlers } \\
\text { (passing from 0 \% to 25\%) }\end{array}$ & 9.00 \\
Communist dummy & -11.85 \\
& -1.07 \\
New Europes dummy & 0.19 \\
Private credit & -2.52 \\
Secondary schooling in 1970 & -1.81 \\
Mature & 0.38 \\
Inflation & 0.88 \\
Arable land per capita & 1.60 \\
Political rights & -0.91 \\
GDP per capita & \\
(largest possible effect) & \\
\hline
\end{tabular}

These are the effects of a one standard error increase of the explanatory variable on the Gini coefficient, except for dummy variables and where indicated.

The effects are obtained using the coefficients in the last OLS regression in Table 2. 
Table 6

Robustness checks

Dependent variable: gini coefficient of the distribution of income

(1)

(2)

(3)

Percentage of European settlers

$0.45^{\star \star *} \quad 0.47^{* * *} \quad 0.35^{\star * *}$

New Europes dummy

Communist dummy

Private credit

Secondary schooling in 1970

Mature

Inflation

Arable land per capita

Political rights

GDP per capita

GDP per capita squared

$\begin{array}{ccc}-0.80 & -0.85 & -3.32^{* *} \\ -11.81^{* * *} & -12.04^{* * *} & -12.60^{* * *} \\ 0.010 & 0.00015 & -0.008 \\ -0.073^{* * *} & -0.106^{* * *} & -0.132^{* * *} \\ -0.22^{* *} & -0.29^{* *} & -0.24^{* *} \\ 0.0044 & 0.0026 & 0.0002 \\ 2.19^{* * *} & 2.61^{* * *} & 3.88^{* * *} \\ 0.56^{* *} & 0.80^{* * *} & 0.94^{* * *} \\ -0.00034^{* * *} & -0.00021 & -0.00013 \\ 1.02 \times 10^{-8 * * *} & 9.34 \times 10^{-9 * *} & 8.25 \times 10^{-9 * * *}\end{array}$

Latin American dummy

$-0.61$

Sub-Saharan Africa dummy

$6.62^{* * *}$

Dummy for Spanish colonies

Dummy for French colonies

Dummy for British colonies

$-2.09$

1.36

1.64

Dummy for slave colonies

$6.50^{* * *}$

Sample

Countries included

Number of obs.

$1977-199$
82

$\begin{array}{cr}7-1997 & 1977-1997 \\ 82 & 82 \\ 470 & 470\end{array}$

1977-1997

$\mathrm{R}^{2}$

0.74

0.73

82

470

White heteroskedasticity - consistent standard errors have been used. 